\title{
APLIKASI SISTEM PAKAR PERAWATAN KOMPUTER UNTUK MENDUKUNG KEGIATAN BELAJAR MENGAJAR DALAM MENINGKATKAN PELAYANAN SISWA
}

\author{
M. Yusuf Effendy ${ }^{* 1}$, Sutrisno ${ }^{2}$, Ahmad Mustopa ${ }^{3}$ \\ 1,2,3 Program Studi Teknik Informatika Universitas Raharja \\ email : yusuf.effendy@ raharja.info ${ }^{1}$, sutrisno@ raharja.info², mustopa@ raharja.info ${ }^{3}$
}

\begin{abstract}
Abstrak
Untuk mendiagnosa kerusakan suatu komputer, dibutuhkan waktu yang cukup lama, terkadang teknisi sering kali tidak menyelesaikan tugasnya agar bias memperbaiki sebagai solusi kerusakan komputer. Untuk menyimpulkan solusi kerusakan komputer, sebenarnya sudah ada standar penyelesaiannya, hal ini sangat memungkinkan agar dapat dibuatkan sebuah sistem yang mampu berjalan secara otomatis berdasarkan gejala yang muncul. Pembuatan sistem pemeriksaan kerusakan komputer sebagai sebuah alat bantu dalam perawatan sebuat laboratorium komputer bisa diselesaikan dengan menggunakan beberapa metode, seperti metode forward chaining atau backward chaining. Selain itu pemodelan sistem ini juga menggunakan metode perancangan uml yang melibatkan usecase diagram, activity diagram, sequence diagaram, kemudian untuk menggabarkan sebuah database yang memunculkan table apa saja yang diperlukan, juga digunakan class diagram sebagai analisa data. Terdapatnya beberapa table initi seperti gejala, masalah, solusi dan table persilangan diantara ketiganya akan mampu menciptakan beberapa langkah penyelesaian yang standar, sehingga diharapkan sistem ini mampu membantu para teknisi dalam rangka merawat komputer dalam sebuah laboratorium dengan cepat dan tepat.
\end{abstract}

Kata kunci : Sistem pakar,kerusakan komputer, Forward chaining

\begin{abstract}
To diagnose damage to a computer, it takes quite a long time, sometimes technicians often do not complete the task so that the bias can be repaired as a solution to computer damage. To conclude a computer damage solution, there is actually a standard solution, this is very possible so that a system that can run automatically based on the symptoms that can be created. Making a computer damage inspection system as an aid in the maintenance of a computer laboratory can be completed using several methods, such as the forward chaining or backward chaining method. In addition, this system modeling also uses the uml design method which involves usecase diagrams, activity diagrams, sequence diagrams, then to describe a database that raises what tables are needed, also used class diagrams as data analysis. The existence of several initi tables such as symptoms, problems, solutions and cross tables between the three will be able to create a number of standard completion steps, so it is hoped that this system is able to assist technicians in maintaining computers in a laboratory quickly and accurately.
\end{abstract}

Keywords: Expert System, Computer damage,Forward Chaining

\section{PENDAHULUAN}

Sesuai perubahan zaman yang menuntut kecepatan dalam melaksanakan berbagai kegiatan, kebutuhan akan teknonogi informasi dan komunikasi pun semakin besar dan meluas termasuk dalam dunia pendidikan [3], bahkan penggunaan TIK tidak hanya sebatas membantu 
manajemen sekolah akan tetapi bahkan diterapkan dalam sebuah mata pelajaran khusus. mampu pelajaran teknologi informasi, komputer merupakan sarana utama untuk pembelajaran dalam mendukung kegiatan belajar siswa. Keberadaan laboratorium komputer diharapkan dapat mengembangkan kemampuan peserta didik bidang teknologi informasi.

Sekolah tempat objek penelitian memiliki fasilitas laboratorium yang memadai untuk proses pembelajaran teknologi informasi bagi siswa. Dengan seiring waktu sering terpakainya komputer banyak unit-unit komputer yang mulai mengalami kerusakan pada bagian hardware maupun software, kerusakan unit-unit tersebut membuat terhambatnya proses pembelajaran teknologi informasi dan komunikasi dan dalam proses perbaikan maupun perawatan yang di lakukan saat inimasih melakukan secara manual dan membutuhkan waktu yang cukup lama dalam melakukan proses perbaikan maupun perawatan komputer tersebut agar tingkat pelayanan pada siswa-siswi lebih meningkat.

Berdasarkan kebutuhan yang ada, dibutuhkan peningkatan mutu dalam perbaikan maupun perawatan komputer dengan secara cepat dan tepat dalam menangani permasalahan kerusakan-kerusakan unit komuputer hardware untuk perawatan komputer itu sendiri agar mendapatkan hasil yang lebih baik dari sebelumnya, penulis mengharapkan adanya aplikasi sistem pakar perawatan komputer untuk meningkatkan pelayanan siswa agar dapat di mamfaatkan agar mencapai hasil yang maksimal. Oleh karena itu, dengan adanya sistem pakar ini, diharapkan perawatan laboratorium menjadi lebih cepat dan akurat dan membutuhkan waktu yang lebih singkat untuk meningkatkan pelayanan siswa.

Perancangan Sistem adalah suatu kegiatan membuat desain teknis berdasarkan kegiatan pada waktu proses analisis. Perancangan disini dimaksudkan suatu proses pemahaman dan peran suatu sistem informasi berbasis komputer [1][9]. Dalam konsep sistem pakar, pengguna menyampaikan fakta dan informasi ke dalam sistem pakar, yang selanjutnya fakta dan informasi akan disimpan ke knowledgebase dan diolah oleh mesin inferensi, sehingga sistem mampu memberikan timbal balik kepada user berupa jawaban berdasarkan pengetahuan yang sebelumnya [2][10]. Sistem pakar adalah suatu sistem berbasis komputer yang mengadopsi pengetahuan manusia ke komputer, agar komputer dapat menyelesaikan masalah seperti yang oleh para ahli. [4]

Forward Chaining merupakan cara penalaram yang dimulai dari fakta, untuk menguji kebenaran hipotesis / mencocokan fakta / pernyataan dimulai dari bagian sebalah kiri [17]. Forward Chaining juga merupakan grup multiple inferensi dengan melakukan pencarian masalah dan solusinya. Jika sesuai dengan situasi (bernilai TRUE), maka proses akan mengassert konklusi [18]. Forward Chaining cocok digunakan untuk suatu aplikasi berbasis sistem pakar [5][6].

Backward Chaining merupakan cara penalaran dengan memulai dari hipotesis (ekspektasi apa yang diinginkan terjadi) terlebih dahulu, dan untuk menguji kebenaran hipotesis tersebut harus dicari fakta-fakta yang ada dalam basis pengetahuan. Backward Chaining merupakan juga penalaran dengan melakukan pencocokan fakta dengan pernyataan yang dimulai sebelah kanan (THEN dulu)[19][20]. Backward Chaining cocok digunakan untuk aplikasi yang menghasilkan tree yang terbatas dan cukup luas. [7][8]. Permasalahan kerusakan pada komputer menjadi masalah yang rumit karena pengguna komputer kurang memiliki pengetahuan, khususnya dalam kerusakan hardware komputer, hal ini secara umum dialami oleh individu maupun oleh institusi. Banyaknya dana yang keluar dalam memperbaiki komputer, merupakan suatu pemborosan, walaupun kerusakan komputer yang terjadi belum tentu rumit dan dapat diperbaiki secara mandiri. Berdasarkan hal diatas, penulis mencoba membangun sebuah aplikasi yang membantu mempermudah pengguna komputer dalam memberikan solusi kerusakan komputer dengan cepat yaitu.

\section{METODE PENELITIAN}

Metode penelitian merupakan suatu tata cara atau kegiatan penelitian dalam rangka mengumpulkan informasi atau data, sekaligus melakukan investigasi terhadap data yang didapat, yang didasari oleh asumsi dasar, pandangan filosofis dan ideologis, pertanyaan dan isu 
yang dihadapi [11][12]. Suatu penelitian mempunyai bentuk rancangan penelitian tertentu. Rancangan ini dapat menggambarkan prosedur atau langkah yang harus ditempuh, waktu penelitian, sumber data dan kondisi arti untuk apa data dikumpulkan dan dengan cara bagaimana data tersebut dihimpun dan diolah untuk dianalisa dalam pembuatan laporan [13][16].

\subsection{Metode Observasi (Observasi Research)}

Pada tahapan ini penulis melakukan pengamatan langsung terhadap obyek penelitian untuk mendapatkan data atau informasi yang akurat dari berbagai pihak yang terkait yang berhubungan tema penelitian.

a.

Metode Wawancara (Interview Research)

Penulis melakukan wawancara dengan penanggungjawab komputer yang mengolah data komputer, penulis mendapatkan informasi berkaitan dengan penelitian penulis.

b.

Metode Studi Pustaka (Studi Literature)

Selain melakukan observasi, penulis juga melakukan pengumpulan data yang dibutuhkan dengan cara studi pustaka. Penulis berusaha untuk melengkapi data yang diperoleh dengan mempelajari dari buku-buku dan data-data yang relevan. Buku dan data tersebut digunakan penulis untuk membantu penganalisaan dan perancangan yang dilakukan.

\subsection{Metode Analisis Data}

Pada penelitian ini, metode analisa dilakukan dengan langkah-langkah melakukan pengamatan dan analisa terhadap sistem yang berjalan saat ini, serta menentukan UML (Unified Modeling Language) yang meliputi use case diagram, activity diagram, sequence diagram.

\section{HASIL DAN PEMBAHASAN}

Untuk dapat menggambarkan prosedur secara keseluruhan diperlukan bebrapa tahapan analisa sebagai bentuk pengumpulan informasi guna mendapatkan model yang sesuai dengan kebutuhan dan mampu memberikan solusi dengan cepat secara efektif dan efisien, mulai dari tahapan pengumpulan informasi dan kebutuhan, analisa dokumen, merancangan hubungan antar dokumen sampai dengan merancanga model diagram database dan model rancangan sistem. Beberapa tahapan yang dimaksud sampai dengan model ranangan yang diciptakan dapat dilihat pada gambar 1,2,3,4,5.

\subsection{Use Case Diagram Prosedur Berjalan}

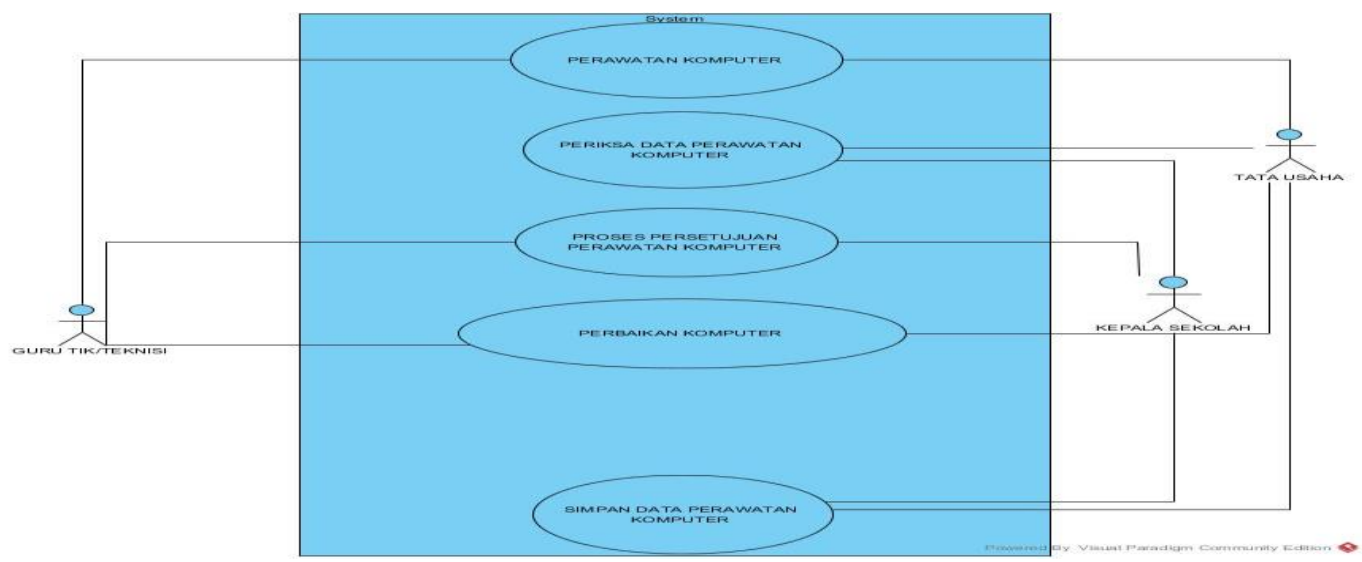

Gambar 1. Use Case Diagram

Berdasarkan gambar use case Diagram (gambar 1) yang berjalan saat ini sistem yang mencakup seluruh kegiatan pada sistem pelaporan perawatan komputer. Terdapat 3 (tiga) Actor yang melakukan kegiatan yaitu guru teknik informatika komputer/ teknisi, tata usaha, kepala sekolah, yang berfungsi menangani pembuatan data perawatan komputer, penerima data perawatan komputer, proses persetujuan perawatan komputer, pebaikan komputer, simpan data perawatan komputer. 
Terdapat juga 4 (usecase) use case yang merupakan proses yang terjadi pada sistem berjalan yaitu pembuatan data perawatan komputer yang melibatkan guru teknik informatika komputer/ teknisi dan tata usaha, menerima data perawatan komputer yang melibatkan tata usaha dan kepala sekolah, proses persetujuan perawatan komputer yang melibatkan guru teknik informatika dan kepala sekolah, perbaikan komputer yang melibatkan guru teknik informatika/teknisi dan tata usaha, simpan data perawatan komputer yang terlibat tata usaha dan kepala sekolah.

\subsection{Activity Diagram Prosedur Berjalan}

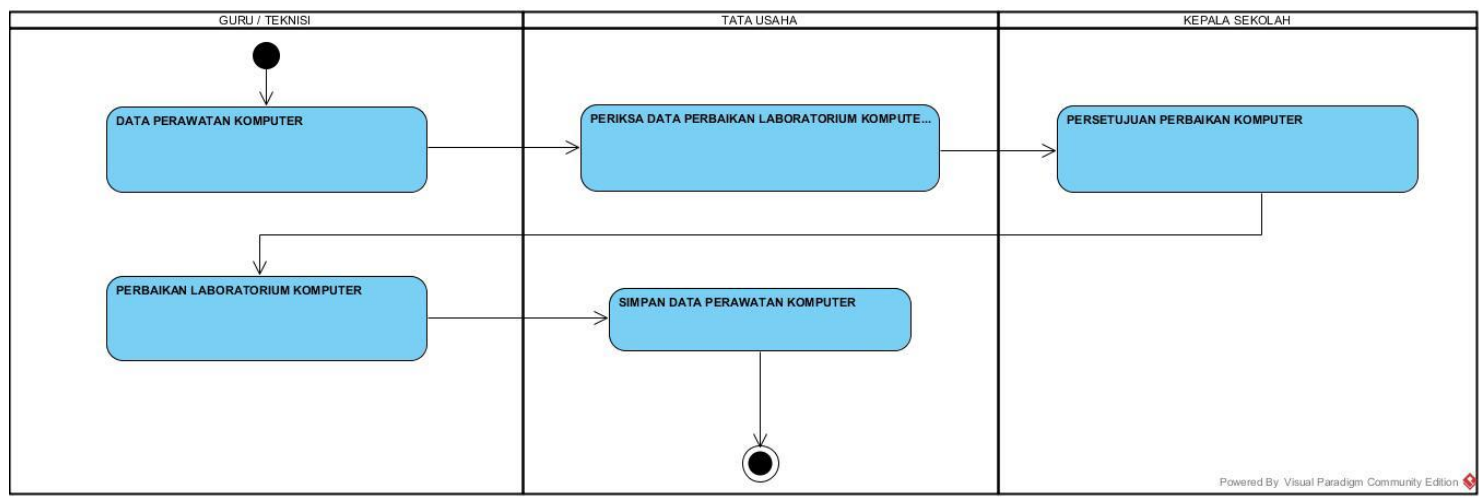

Gambar 2. Activity Diagram

Berdasarkan gambar activity diagram (gambar 2) yang berjalan saat ini sistem mencakup seluruh kegiatan pelaporan peerawatan komputer. Sistem ini melibatkan 3 (tiga) Actor yaitu, guru teknik informatika komputer/teknisi yang menangani pembuatan data komputer dan perbaikan komputer, tata usaha yang menangani penerima data perawatan komputer dan penyimpanan data perawatan komputer, kepala sekolah yang menangani persetujuan perbaikan komputer.

\subsection{Squence Diagram Prosedur Berjalan}

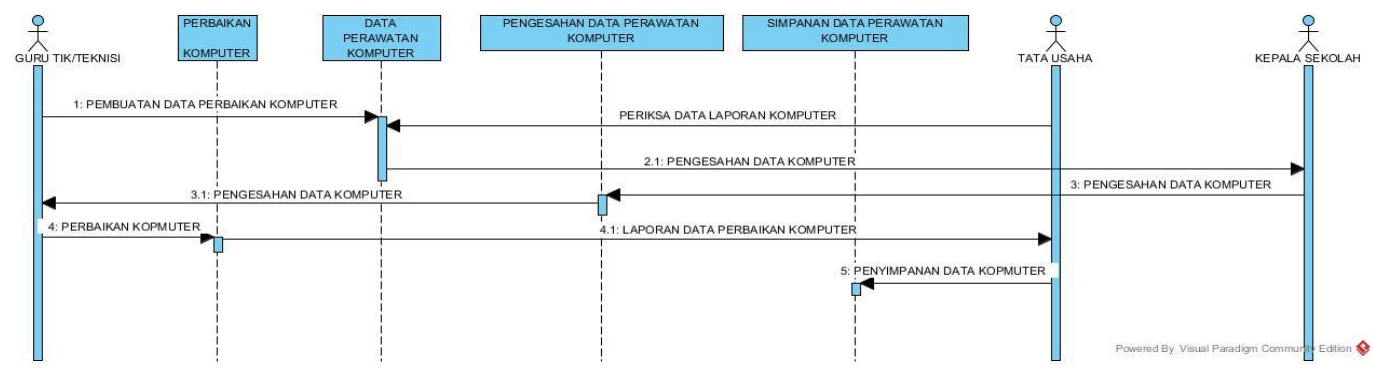

Gambar 3. Squence Diagram

Berdasarkan gambar sequence diagram (gambar 3) yang berjalan saat ini terlihat 3 (tiga) actor yang melakukan kegiatan diantaranya: guru teknik informatika komputer, tata usaha dan kepala sekolah, yang akan menyelesaikan 8 message spesifikasi dari komunikasi antar objek yang memuat informasi-informasi tentang aktifitas yang terjadi, yaitu peembuatan data perawatan komputer, periksa data perawatan komputer, pengesahan data perawatan komputer, pengesahan data komputer, pengesahan data komputer, perawatan komputer, laporan data perawatan komputer, penyimpanan data perawatan komputer.

Rancangan diatas (gambar 1, 2, 3) merupakan gambaran prosedur yang berjalan dimana pada tahapan ini melibatkan dokumen data perawatan komputer. Dimana data perawatan komputer akan di disi oleh guru teknik informatika komputer / teknisi yang berfungsi sebagai 
data perawatan komputer yang menghasilkan data perawatan laporan perawatan komputer. Dokumen ini diharapkan dapat membantu pengelola untuk dapat memberikan pelayanan terbaik dengan menjaga kinerja kompuer melalui perawatan komputer yang maksimal.

\subsection{Class Diagram}
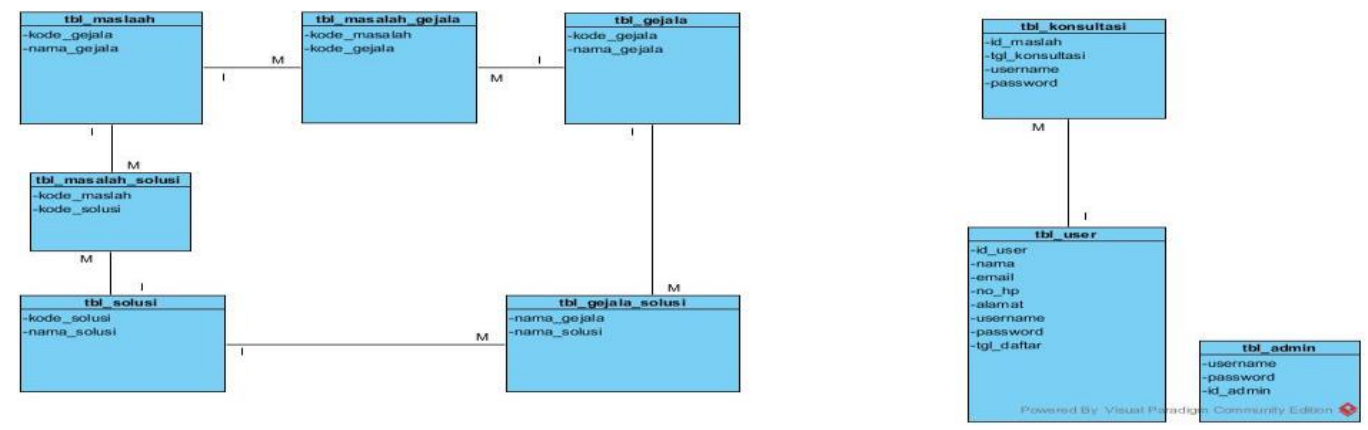

Gambar 4. Class Diagram

Berdasarkan gambar class diagram (gambar 4) yang berjalan saat ini sistem yang mencakup seluruh kegiatan pada sistem pelaporan hutang dagang. Terdapat 9 (sembilan) class yaitu user, tbl_konsultasi, tbl_admin, tbl_gejala, tbl_gejala_solusi, tbl_tbl_solusi, tbl_masalah_solusi, tbl_masalah, tbl_masalah_gejala

Berdasarkan gambar class diagram (gambar 4) diatas dapat dilihat dengan jelas bahwa tingkat hubungan tbl_user dan tbl_konsultasi yaitu one to many (1:M), tingkat hubungan tbl_user dan tbl_admin one to one (1:1), tbl_masalah_gejala tercipta karena adanya tingkat hubungan many to many (M:M) antara tbl_masalah dan tbl_gejala. tbl_masalah_solusi tercipta karena adanya tingkat hubungan many to many (M:M) antara tbl_masalah dan tbl_solusi. tbl_gejala_solusi tercipta karena adanya tingkat hubungan many to many (M:M) antara tbl_gejala dan tbl_solusi.

\subsection{Use Case Diagram Usulan}

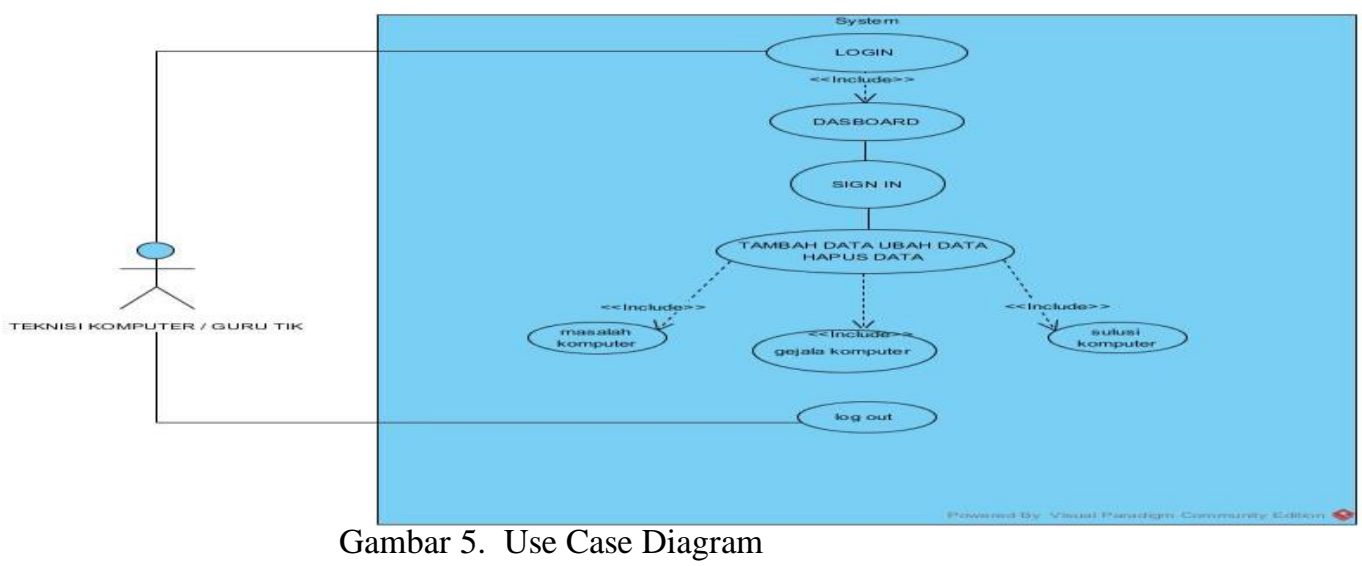

Berdasarkan gambar use case diagram usulan (gambar 5) terlihat jelas bahwa terdapat 8 (delapan) use case yang terdiri dari 3 (tiga) use case utama yaitu login, dashboard, pengolahan data. Use case pengolahan data memiliki 3 (tiga) yang terdiri dari nama masalah komputer, gejala komputer, solusi komputer. Dimana seluruh use case masing-masing terhubung dengan admin, dan beberapa use case yang terkait dengan user terhubung dengan user dalam hal menjawab pertanyaan untuk mencari solusi. Use case login sebagai verifikasi pengguna yang berhak dengan username dan password dan use case logout untuk menutup system dengan aman. 
Use diagram sebagai bentuk rancangan sistem yang akan diciptakan (gambar 5) merupakan desain model tampilan utama yang berorintasi pada kebutuhan menu pada aplikasi yang disiapkan, selain itu untuk kebutuhan penyimanan informasi data agar dapat digunakan secara histori juga digambarkan dalam bentuk class diagram (gambar 4) lengkap dengan informasi field dan type data sesuai kebutuhan penyimpanan data.

\subsection{Rancangan Basis Data}

Untuk dapat menggamarkan bentuk basis data secara utuh, peneliti penggunakan aplikasi microsoft access sebagai bentuk gambaran dasar, dan pada akhirnya bentuk rancangan basis data ini dapat disesuaikan menggunakan apa saja sesuai kebutuhan.

\section{a. Tabel Master: User}

Primary Key : id_user

Foreign Key : :

Structure Tabel : \{ id_user, nama, email, no_hp, alamat, username, password, tgl_daftar \}

\begin{tabular}{|c|c|c|c|c|c|c|c|}
\hline & \# & Name & Type & Collation Attributes & NuII & Default & Extra \\
\hline$\Xi$ & 1 & id_user 0 & int (10) & & No & None & AUTO_INCREMENT \\
\hline$\square$ & 2 & nama & varchar(15) & & res & Nivis & \\
\hline$\square$ & 3 & email & text & & res & NULEL & \\
\hline$\square$ & 4 & no_hp & varchar(12) & & res & NULE & \\
\hline$\square$ & 5 & alamat & text & & res & NUEL & \\
\hline$\square$ & E & username & varchar(10) & & res & MiLes & \\
\hline$\square$ & 7 & passurord & varchar(10) & & Yes & NuLE & \\
\hline$\square$ & 8 & tgl_daftar & datetime & & res & NuLiLL & \\
\hline
\end{tabular}

Tabel 1. Struktur User

b. Tabel Master: admin

Primary Key : id_admin

Foreign Key : :

Structure Tabel : \{id_admin, Nama, username, password \}

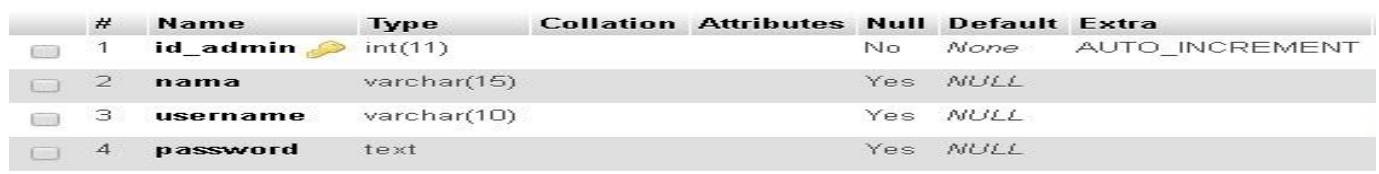

Tabel 2. Struktur Admin

c. Tabel Master: tbl_gejala_solusi

Primary Key : kode_gejala, Kode_solusi

Foreign Key : -

Structure Tabel : \{kode_gejala, Kode_solusi \}

\begin{tabular}{|lllll} 
\# & Name & Type & Collation Attributes Null Default Extra \\
\hline 1 & kode_gejala $\gg$ varchar(4) & No Mone \\
2 & kode_solusi $\&$ varchar(4) & No None
\end{tabular}

Tabel 3. Struktur kode_gejala_solusi

d. Tabel Transaksi: kode_masalah_gejala

Primary Key : kode_masalah, kode_gejala

Foreign Key : -

Structure Tabel : \{kode_masalah, kode_gejala $\}$

\begin{tabular}{|llll} 
\# & Name & Type Collation Attributes & Null Default Extra \\
\hline 1 & kode_masalah & varchar(4) & No None \\
2 & kode_gejala & varchar(4) & No None \\
\hline$\square$
\end{tabular}

e. Tabel Transaksi: kodeTabelst.lafhrusolusdiode_masalah_gejala 
Primary Key : : kode_masalah, kode_solusi

Foreign Key : -

Structure Tabel : \{kode_masalah, kode_solusi \}

\begin{tabular}{|lllll}
\hline$H$ & Name & Type & Collation Attributes Null Default Extra \\
\hline 1 & kode_masalah & varchar(4) & No None \\
\hline 2 & kode_solusi & varchar(4) & No Rone \\
\hline$\square$
\end{tabular}

Tabel 5. Struktur kode_masalah_solusi

f. Tabel Transaksi: tbl_masalah

Primary Key : kode_masalah

Foreign Key : -

Structure Tabel : \{kode_masalah, nama_masalah, tgl_masalah

\begin{tabular}{|cllll}
\hline$H$ & Name & Type & Collation Attributes Null Default Extra \\
\hline 1 & kode_masalah & varchar(4) & No None \\
\hline 2 & nama_masalah & text & Yes NiLL \\
\hline 3 & tgl_masalah & datetime & Yes NiLL \\
\hline
\end{tabular}

Tabel 6. Struktur tbl_masalah

g. Tabel Transaksi: tbl_gejala

Primary Key : kode_gejala

Foreign Key :

Structure Tabel : \{ kode_gejala, nama_gejala,tgl_gejala $\}$

\begin{tabular}{|c|c|c|c|c|c|c|c|c|}
\hline & $H$ & Name & Type & Collation & Attributes & Null & Default & Extra \\
\hline$\square$ & 1 & kode_gejala & varchar(4) & & & No & None & \\
\hline$\square$ & 2 & nama_gejala & text & & & Yes & NULC & \\
\hline$\square$ & 3 & tgl_gejala & datetime & & & Yes & NULL & \\
\hline
\end{tabular}

h. Tabel Transaksi: tbl_solusi

Tabel 7. Struktur tbl_gejala

Primary Key : kode_solusi

Foreign Key : -

Structure Tabel : \{kode_solusi, nama_solusi, tgl_solusi \}

\begin{tabular}{|lllll}
$H$ & Name & Type & Collation Atributes Null Default Extra \\
\hline 1 & kode_solusi & varchar(4) & No None \\
2 & nama_solusi & text & Ves NiLL \\
\hline & tgl_solusi & datetime & Yes NiLL
\end{tabular}

Tabel 8. Struktur tbl_solusi

i. Tabel transaksi: tbl_konsultasi

Primary Key : kode_masalah

Foreign Key : -

Structure Tabel : \{kode_masalah,tgl_konsultasi, username, password \}

\begin{tabular}{|lllll}
\hline$H$ & Name & Type & Collation Attributes Null Default Extra \\
\hline 1 & kode_masalah & varchar(4) & No None \\
\hline 2 & tgl_konsultasi & datetime & No None \\
\hline 3 & username & varchar(10) & No None \\
\hline 4 & password & text & No None
\end{tabular}

Tabel 9. Struktur tbl_konsultasi 


\subsection{Grafik Status Keadaan Komputer}

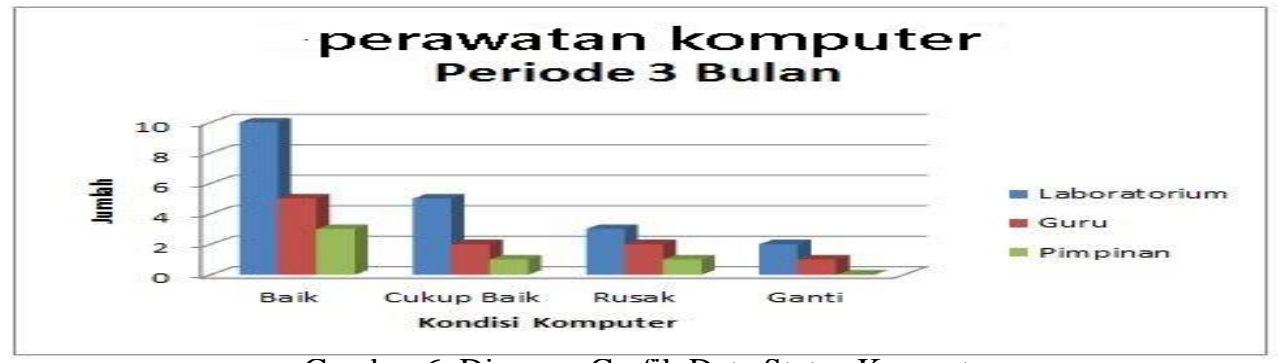

Gambar 6. Diagram Grafik Data Status Komputer

Grafik diatas (gambar 6) merupakan grafik monitoring perawatan komputer berdasarkan waktu (bulan). Hal ini bisa membantu manajemen dalam menunjang keputusan guna perawatan komputer.

\subsection{Diagram HIPO}

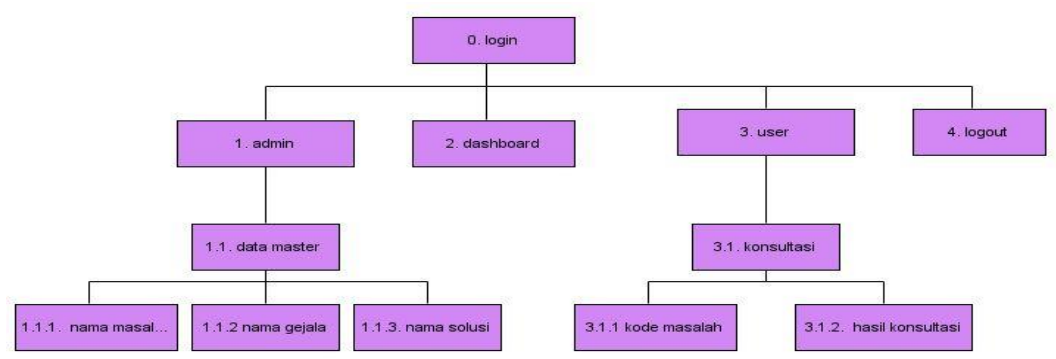

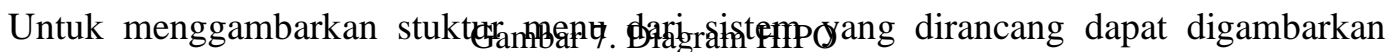
dengan diagram HIPO (Hierarchy Input Process Output). Untuk menyediakan suatu struktur guna memahami fungsi-fungsi dari program. Terlihat dari diagram HIPO diatas (gambar 7) terdapat 1 (satu) fungsi utama (digram 0) dan 4 (empat) fungsi dibawahnya, yaitu fungsi menu admin (diagram 1), menu dashboard (diagram 2), menu user (diagram 3) dan menu logout (diagram4). Didalam fungsi menu admin (diagram 1) terdapat 1 (satu) fungsi sub menu yaitu data master (diagram 1.1), didalam fungsi sub menu data master (diagram 1.1) terdapat 3 (dua) fungsi sub menu yaitu nama masalah (diagram 1.1.1.) nama masalah (diagram 1.1.2.) dan nama solusi (diagram 1.1.3.) . Didalam fungsi menu user (diagram 3) terdapat 1 (satu) fungsi sub menu yaitu konsultasi (diagram 3.1), didalam fungsi sub menu konsultasi (diagram 3.1) terdapat 2 (dua) fungsi sub menu yaitu kode masalah (diagram 3.1.1.) dan hasil konsultasi (diagram 3.1.2.)

\subsection{Rancangan Tampilan}

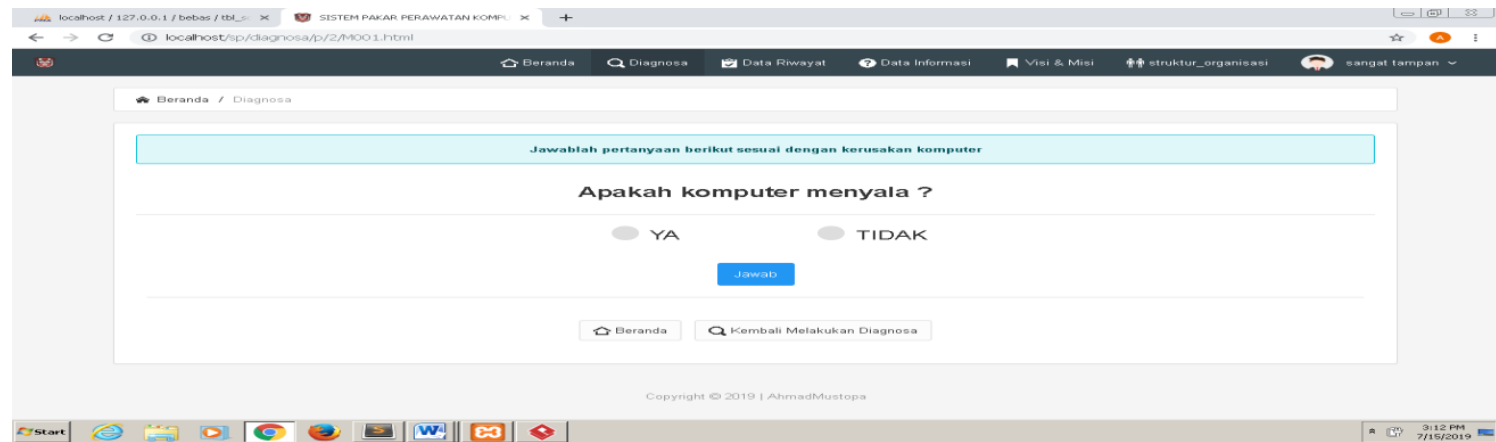


Terlihat pada tampilan layar diatas (gambar 8) merupakan tampilan layar halaman mulai konsultasi yang berisi masalah kerusakan komputer.

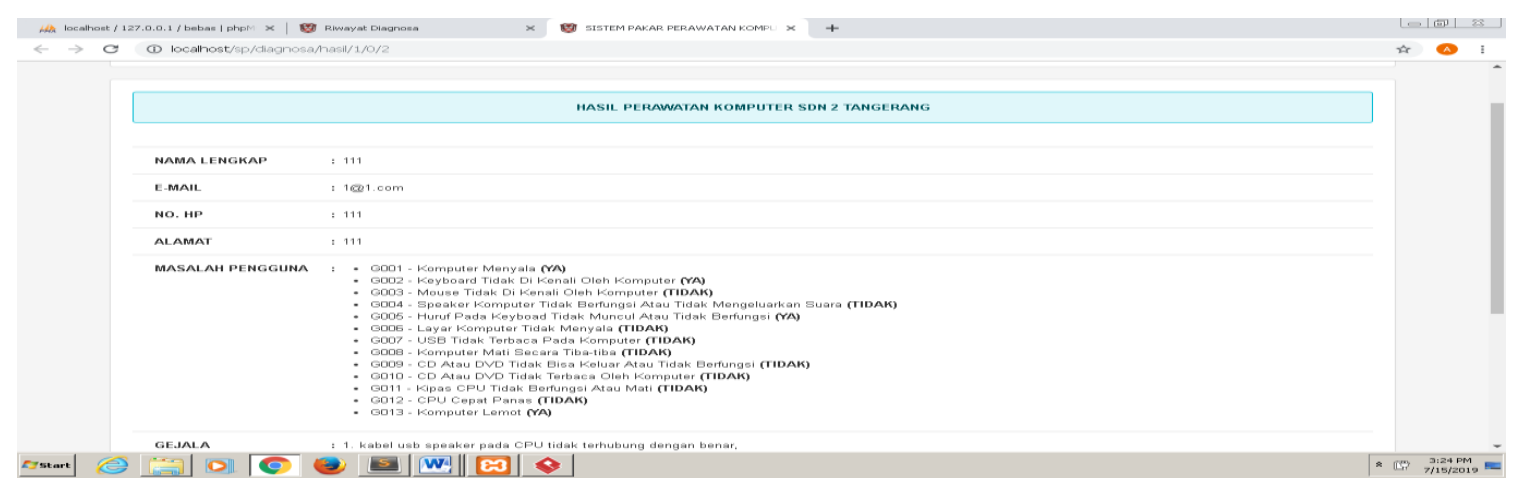

Gambar 9. Tampilan Halaman Hasil Konsultasi

Terlihat pada tampilan layar diatas (gambar 9) merupakan tampilan layar hasil konsultasi yang berisi data masalah, data gejala dan data solusi.

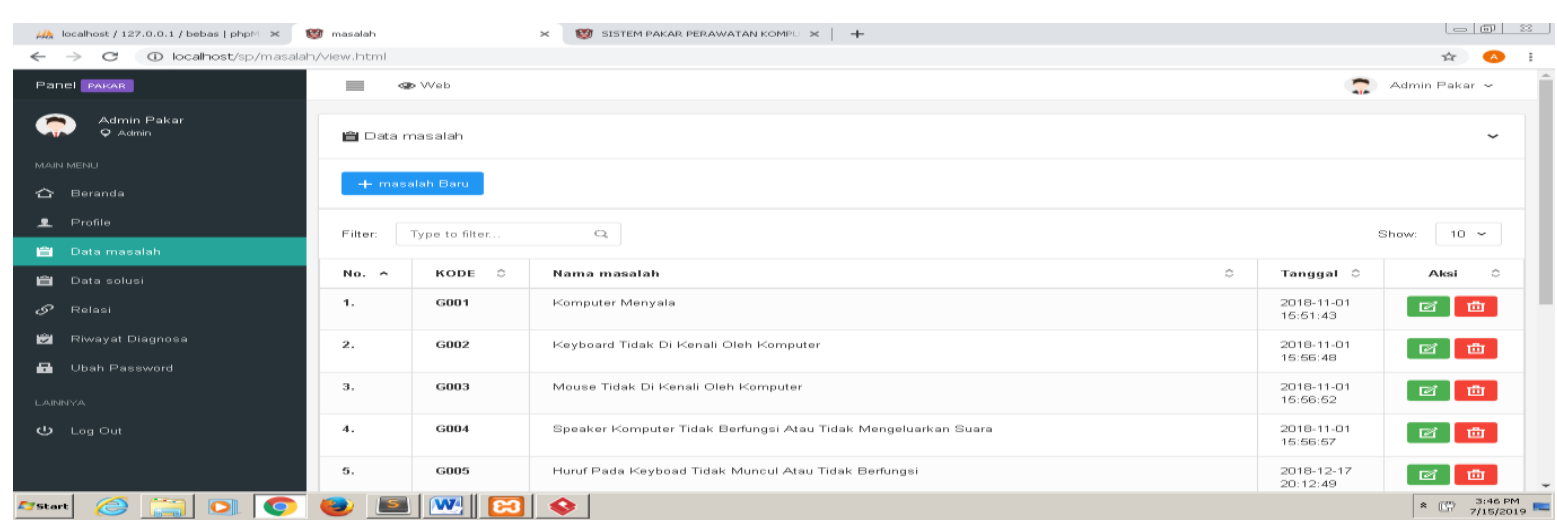

Gambar 10. Tampilan Halaman Data Masalah

Terlihat pada tampilan layar diatas (gambar 10) merupakan tampilan layar data masalah yang terdiri dari kode masalah, nama masalah dan tanggal masalah.

\subsection{Query Penciptaan Informasi}

public function view $(\$ a k s i=", \$ i d=")$

$\{$ \$ceks $=$ \$this->session-> userdata('username');

\$id_user $=\$$ this->session-> userdata('id_user');

if(!isset(\$ceks)) \{ redirect('web/login'); \}else\{

\$data['user'] = \$this->db->get_where('tbl_pakar', "username='\$ceks'");

\$this->db->order_by('kode_masalah', 'ASC');

\$data['sql'] = \$this->db->get("tbl_masalah");

if $(\$ a k s i==$ 't') \{

$\$ \mathrm{p}=$ "tambah";

\$data['judul_web'] = "+ masalah";

\}elseif (\$aksi == 'e') \{

$\$ \mathrm{p}=$ "edit";

\$data['judul_web'] = "Edit masalah"; $>\operatorname{row}()$;

\$data['query'] = \$this->db->get_where("tbl_masalah", array('kode_masalah' => "\$id"))-

if (\$data['query']->kode_masalah==") $\left.\left\{\operatorname{redirect}\left({ }^{\prime} 404 '\right) ;\right\}\right\}$ 


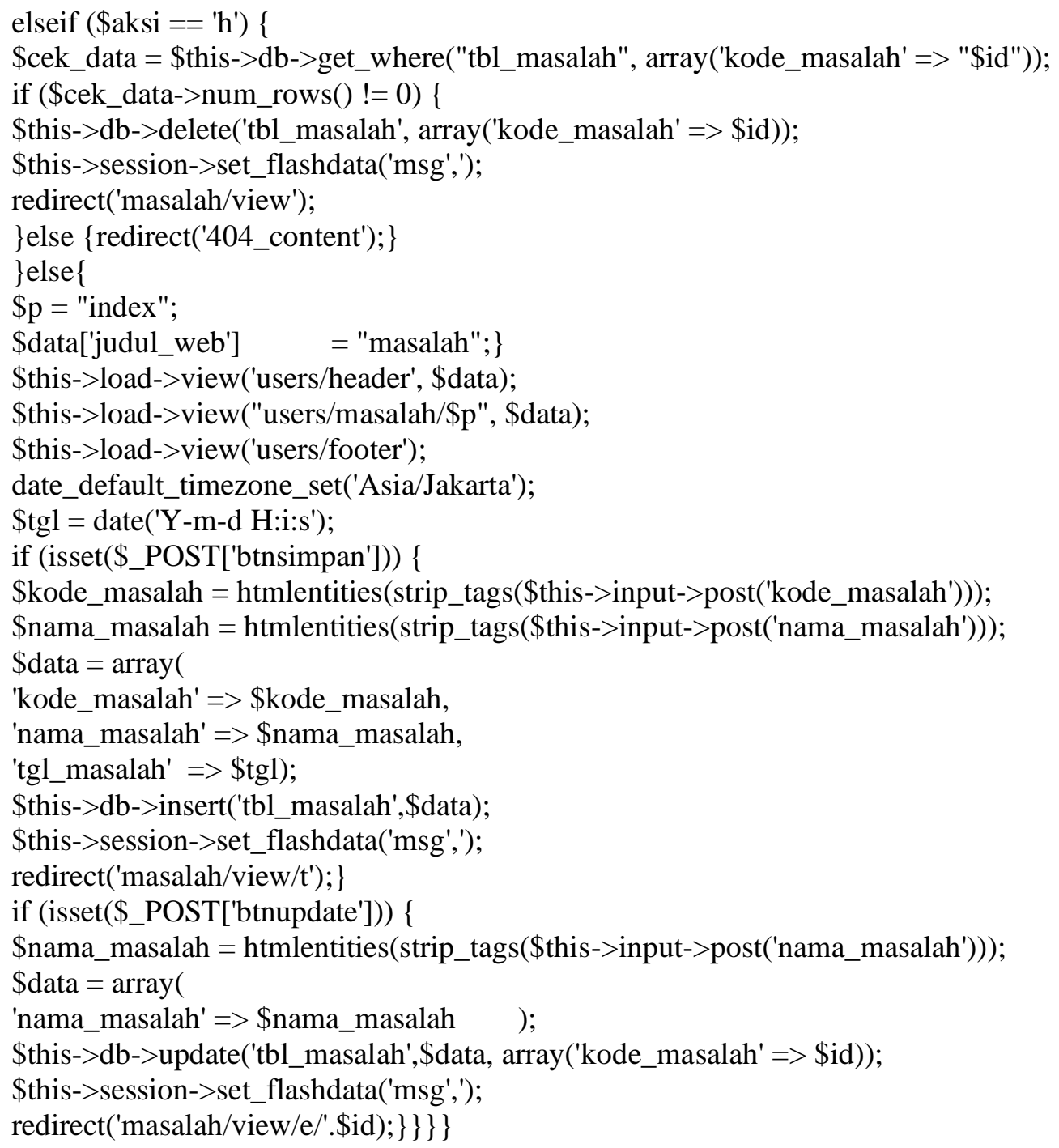

\section{KESIMPULAN}

Berdasarkan analisa yang dilakukan dapat disimpulkan sebagai bahwa penginputan dan penyimpanan data perawatan komputer yang sekarang ini masih dengan cara yang manual, masih banyak membutuhkan form kertas, buku dan waktu. Teknisi komputer membutuhkan waktu yang cukup lama dalam mendiagnosa kerusakan pada sebuah komputer. Sering kali teknisi menunda pekerjaannya untuk menghasilkan solusi dari kerusakan komputer. Solusi dari permasalahan dengan merancang aplikasi menggunakan metode forward chaining dan certainty factor dimana metode forward chaining sebagai proses pelacakan sedangkan metode certainty factor merupakan cara untuk membuktikan apakah suatu fakta itu pasti ataukah tidak pasti. Metode ini cocok untuk sistem pakar yang mendiagnosa sesuatu yang belum pasti dengan teknik melakukan perhitungan untuk menentukan nilai keyakinan. Manfaat dari sistem pakar yaitu mampu melakukan diagnosa dengan tepat dan akurat, berdasarkan gejala kerusakan. 


\section{DAFTAR PUSTAKA}

[1] Junaidi, J., Roji, A., \& Munawar, K. (2015). Konsep Otomatisasi Sistem Pembayaran SPP Online Untuk Mengurangi Tingkat Keterlambatan. Proceedings Konferensi Nasional Sistem dan Informatika (KNS\&I)..

[2] Andriani, Anik. 2016. Pemprograman Sistem Pakar Konsep Dasar dan Aplikasinya Menggunakan Visual Basic 6. Yogyakarta: MediaKom

[3] Junaidi, T. K. Y. N. D. (2013). Sistem Pakar Monitoring Inventory Control Untuk Menghitung Harga Jual Efektif Dalam Meningkatkan Keuntungan. Yogyakarta: Universitas Ahmad Dahlan.

[4] Pusadan, Mohammad Yazdi. (2014:13). Pemprograman MATLAB pada Sistem Pakar Fuzzy. Yogyakarta.

[5] Junaidi, J., Effendy, M. Y., \& Hartono, H. (2015). REKAYASA MODEL APLIKASI SISTEM PRODUCT KNOWLADGE UNTUK MENDUKUNG PENGAMBILAN KEPUTUSAN DALAM MENENTUKAN KINERJA KARYAWAN. CERITA Journal, 1(1), 46-55.

[6] Henderi, H., Junaidi, J., \& Kusuma, T. A. H. (2012). Dashboard Monitoring System Penjualan Dan Reward Mobile Kios PT. Telekomunikasi Seluler. Semantik, 2(1)..

[7] Junaidi, J., Arifin, R., \& Septiani, A. (2015). Rancang Bangun Aplikasi Sistem Inventory Berbasis Desktop Menggunakan JSE. Proceedings Konferensi Nasional Sistem dan Informatika (KNS\&I)..

[8] Tinjauan Studi dari penelitian Nency extise Putri, 2016, STMIK INDONESIA PADANG, dalam Journal Momentum - Volume 18 No 2 - 2016.

[9] Fahmi. 2014. "Pengertian Kinerja Bersifat Profit Oriented dan Non Oriented". Jakarta.

[10] Asbar, Yuli, dan Mochamad Ari Saptari. 2017. "Analisa Dalam Mengukur Kualitas Pelayanan Terhadap Kepuasan Konsumen Menggunakan Metode PIECES". Jurnal Visioner \& Strategis Vol. 6 Nomor 2, September 2017: 39-47 Universitas Malikussaleh.

[11] Junaidi, J., Santoso, S., \& Sunarya, L. (2008). Rekayasa Teknik Pemrograman Pencegahan Dan Perlindungan Dari Virus Lokal Menggunakan API Visual Basic. CCIT Journal, 1(2), 134-153..

[12] Martono, A., \& Junaidi, D. Y. IMULATION GAME BASED ON JARIMAGIC METHOD TO CALCULATE MORE QUICKLY FOR ELEMENTARY STUDENTS.

[13] Junaidi, J., Cholisoh, N., \& Hasanah, N. (2018). Rancang Bangun Sistem Manajemen Aset IT Untuk Pencatatan History Maintenance Sebagai Pendukung Keputusan. SENSI Journal, 4(2), 220-231..

[14] M. Subekti, Warnars Junaidi, H.L.H.S., Y. Heryadi, "The 3 steps of best data warehouse model design with leaning implementation for sales transaction in franchise restaurant", Cybernetics and Computational Intelligence (CyberneticsCom) 2017 IEEE International Conference on, 20-22 Nov 2017.

[15] J. Junaidi, A. Julianto, N. Anwar, S. Safrizal, H.L.H.S. Warnars, K. Hashimoto, "Perfecting a Video Game with Game Metrics", Telkomnika, vol. 16, no. 3, pp. 13241331, June 2018

[16] Zainuddin, A., Junaidi, J., \& Putra, R. D. (2017). Design of E-Commerce Payment System at Tokopedia Online Shopping Site. Aptisi Transactions On Management, 1(2), 143-155.

[17] Junaidi, J., Sutrisno, S., \& Janah, K. (2019). MODEL APLIKASI PURCHASING SYSTEM UNTUK MONITORING STOK DALAM MENGURANGI TINGKAT KERUGIAN. SENSI Journal, 5(1), 86-98.

[18] AMALIA, Riski, et al. PEMODELAN APLIKASI INTEGRATED LEARNING SYSTEM BERBASIS MOBILE. SEMNASTEKNOMEDIA ONLINE, 2013, 1.1: 20-45.

[19] Henderi, H., Nuraeni, Y., Junaidi, J., \& Hidayat, R. (2010). IT GOVERNANCE: A STRATEGIC ALIGNMENT FOR INFORMATION TECHNOLOGY/BUSINESS. CCIT Journal, 4(1), 57-69. 
[20] Junaidi, J., Alfiah, F., Susanti, E., Kristinna, J., Ardiansyah, O. R., Pradipta, D., \& Wulaningsih, W. (2015). MANFAAT MENGANALISIS PENGARUH SOSIAL MEDIA FACEBOOK TERHADAP KAMPANYE PARTAI POLITIK DI INDONESIA. SEMNASTEKNOMEDIA ONLINE, 3(1), 4-5. 